\title{
THE CONCEPTS OF HERITAGE AND HERITAGE RESOURCE APPLIED TO KARSTS: PROTECTING THE CHORANCHE CAVES (VERCORS, FRANCE)
}

\section{ZAMISLI O DEDIŠČINI IN NJENIH VIRIH PRIREJENIH ZA KRAS: VAROVANJE JAM CHORANCHE (VERCORS, FRANCIJA)}

\author{
Christophe GAUCHON ${ }^{1}$, Estelle PLOYON ${ }^{1}$, Jean-Jacques DELANNOY ${ }^{1}$, \\ Sébastien HACQUARD ${ }^{1}$, Fabien HOBLÉA ${ }^{1}$, Stéphane JAILLET ${ }^{1}$, Yves PERRETTE ${ }^{1}$
}

\begin{abstract}
UDC 551.442(44)

Christophe Gauchon, Estelle Ployon, Jean-Jacques Delannoy, Sébastien Hacquard, Fabien Hobléa, Stéphane Jaillet \& Yves Perrette: The concepts of heritage and heritage resource applied to karsts: Protecting the Choranche caves (Vercors, France)

In 2005, French Ministry of Ecology started procedure to inscribe 18 Caves of Chorance into the World Heritage list of UNESCO. The application has to answer to three objectives: the scientific interest, definition of the territory, and to propose the management model. For the first all the heritage sources has to be identified, such as flowstone formations, karst water objects and historical curiosities. This are very important and sensitive questions specially because they have been not answered before the procedure of the inscription started off.

Key-words: karst heritage, karst protection, show cave, classified natural site, caves of Choranche, Vercors, France.
\end{abstract}

Izvleček

UDK 551.442(44)

Christophe Gauchon, Estelle Ployon, Jean-Jacques Delannoy, Sébastien Hacquard, Fabien Hobléa, Stéphane Jaillet \& Yves Perrette: Zamisli o dediščini in njenih virih prirejenih za kras: varovanje jam Choranche (Vercors, Francija)

2005 je francosko Ministrstvo za okolje pričelo postopek za vpis 18 jam okoli Choranche za vpis v svetovno dediščino pri UNESCO. Vloga mora odgovoriti trem merilom: znanstvenemu pomenu, opredelitvi ozemlja in predlagati način upravljanja. Predvsem je bilo treba ugotoviti vse vire dediščine, kot so kapniki, kraški vodni objekti in zgodovinske zanimivosti. To je zelo pomembno in občutliivo vprašanje, še posebej, ker to ni bilo opravljeno, preden je bil sprožen postopek za vpis.

Ključne besede: kraška dediščina, varstvo krasa, turistična jama, zaščitena naravna vrednota, jame Choranche, Vercors, Francija.

\section{INTRODUCTION}

Although France has often played a pioneering role in the exploration and study of caves, the country has done very little to protect the heritage resources of its karst areas. At present, there is no specific legislation covering the protection of karst landscapes - caves and swallow holes can only be protected under general environmental protection laws. Some karsts have been listed as historic monuments, others are protected for their biotopes, four caves have been declared nature reserves and a few hundred others have been classified as "natural sites and monu- ments". The law relating to this final category dates back to 1930 and applies to lakes, waterfalls, peat bogs and coastal dunes, as well as to caverns. The central tenet of this legislation is expressed in Article 12, which stipulates that the "owner of a classified site cannot destroy or modify the state or appearance of that site" without special authorisation. Thus, protection measures are applied on a case-by-case basis, as opportunities arise, and the choice of sites is strongly influenced by the specific interests of the civil servants responsible for the environment.

${ }^{1}$ Laboratoire EDYTEM-University of Savoie, Chambéry, France. e-mail: christophe.gauchon@univ-savoie.fr 
No better illustration of the conservation situation for France's karst heritage can be found than the Choranche Caves network, in the Vercors Mountains. These caves have been explored for over a century and are the most important underground tourist attraction in the French Alps. They feature in every tourist guide and have been the subject of several television programmes; hence, they are quite well known. Dozens of postcards show the forests of soda-straws hanging from the cave roof reflected in the green waters of Lake Coufin. Despite these attri- butes, the site is not covered by any protection measures: only the careful stewardship of the site's owner-managers has maintained the caves in their current condition. A catalogue of the area's main heritage resources has been drawn up as part of the process of granting the area listed-status and introducing official protection measures. However, the numerous objections to the protection proposals show how difficult it can be to protect any area, even a site of universally accepted importance, such as Choranche.

\section{CONTEXT}

In August 2005, the Rhône-Alpes "Direction Régionale de l'Environnement", acting on behalf of the Minister of Ecology, launched a call for tenders for the production of an environmental protection dossier for the "Choranche Caves, surface and subsoil". At the end of the tendering procedure, the bid entered by the EDYTEM laboratory was chosen.

Unusually, the proposal to protect the Choranche Caves was not a response to a clear and immediate threat to the area or the karst system. In this case, the protection process was started as a preliminary step in achieving UNESCO World Heritage status for Choranche and seventeen other French stalactite and stalagmite caves: UNESCO will only accept nominations for sites already protected by the State sponsoring the nomination and this is not the case for some of the caves concerned, including the Choranche Caves.

The 18 caves nominated for UNESCO listing were chosen solely on the basis of the formations they contain, either for their variety (colours, shapes, mineralogy), fragility, rarity or aesthetic quality. Although concretions are relatively abundant throughout the Choranche network, the UNESCO nomination specifically cites the tourist part of the Coufin Cave because of its rich ornamentation. However, it immediately became apparent that in order to effectively protect the site, the protection measures would have to cover a much more extensive area than this one cave. The Choranche Caves consist of a network of more than $40 \mathrm{~km}$ of explored passages, divided into two main and parallel networks (Coufin-Chevaline and Gournier) and containing three underground rivers. The Coufin Cave has been open to tourists since 1967. It remains a popular attraction, although visitor numbers peaked, at more than 200,000 visitors per year, at the beginning of the 1990s. In addition, groups led by State-qualified cave guides frequently visit the Gournier Cave. The network is well understood due to more than 40 years of intense scientific study. On the surface, the Coulmes Plateau also contains a wide range of features that, in our opinion, should be included in the protection dossier.

The environment in which these networks have developed cannot be ignored. The Coulmes Plateau, on the north-western edge of the Vercors, is a true backwater: away from the main through-routes, extremely isolated and with apparently limited potential. The project to give the site listed status is not designed to protect the area from any particular threat; however, it has raised fears amongst some local politicians that it will one day be used to stop future development projects. In fact, the plateau is seen as a neglected area whose development (for example, connection to mains services) is lagging behind that of the villages in the Gorges de la Bourne. The question that arises is whether listing the site will increase the divisions between the gorges and the plateau or enhance their complementarity. This is why any protection measures must take into account social and local geo-political considerations, as well as environmental and heritage aspects.

\section{OBJECTIVES}

Given the above context, the specification laid down by the "Direction Régionale de l'Environnement" stipulated that EDYTEM's work should be divided into a number of phases, to ensure the listing procedure is completed as quickly as possible. 


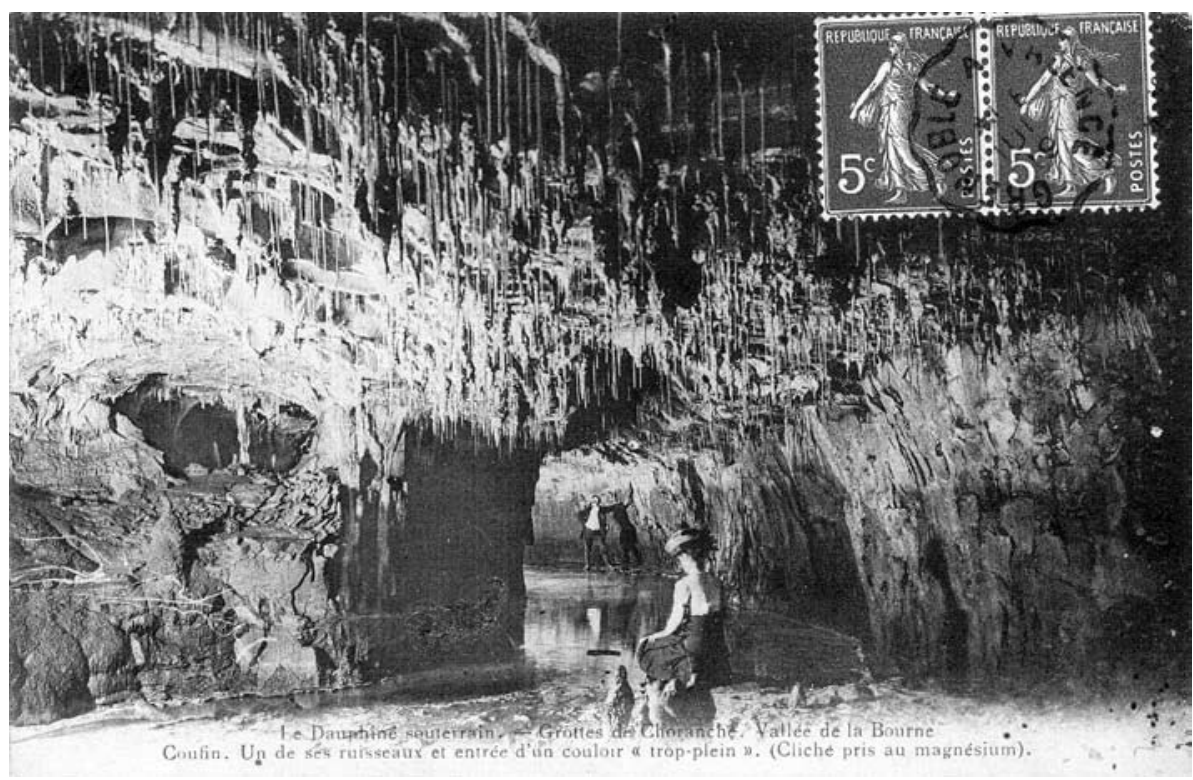

Fig. 1: Visitors in a galery in Coufin cave, postcard, beginning of $X X^{\text {th }}$ century.
First, it was necessary to establish that the site was of "general interest from an artistic, historic, scientific, legendary or picturesque point of view" (art. 4 of the Act of 1930). As the contract covered both the surface and the subsoil, this assessment work had to be applied to the underground karst networks as well as to the external landscapes. The artistic and legendary aspects were quickly eliminated, as they are of little importance in this case. That left the historic, scientific and picturesque dimensions, for which there is a wealth of documentation establishing the heritage value of the Choranche Caves and the Coulmes Plateau. The heritage resources within each of these categories are examined in more detail below.

Next, it was necessary to establish an appropriate, coherent and acceptable protection perimeter. This turned out to be a very sensitive issue. In France, the protection given to karst areas rarely covers entire karst networks unless the system in question contains caves with exceptionally important archaeological remains or cave paintings. There are no accepted standards in cases where karsts are protected for their aesthetic value and to preserve the landscape. Protection measures are generally determined by the beauty of the site and only the land containing the cave is protected, which is a highly unsatisfactory state of affairs. In order to ascertain how the terms of the 1930 Act can be used to give effective protection to karsts, it is necessary to understand what a karst is and how its different elements interact. Should the entire cave be protected, or only the part seen by tourists? For the Coufin, Chevaline and Gournier springs, should protection be limited to the hydrogeological watershed or should the listed area cover the entire karst, with its numerous caverns, its landscapes and all its heritage re- sources? These questions were to become central to the ensuing public debates.

The "Direction Régionale de l'Environnement" also recommended writing management guidelines for the listed area, taking into account all the activities carried out in the massif. In fact, the 1930 Act does not specify which types of development should be allowed or prohibited in a listed area. Therefore, listing the site must be allied with a series of recommendations, based on the specificities of the listed area, that will provide the local authorities with criteria on which to base decisions on whether to authorise future development projects. The protection measures must take into account the farming, forestry, permanent dwellings and numerous sports activities (cross-country skiing, hiking, caving, climbing, hunting, etc) that currently coexist in the Coulmes Plateau area, as the aim is not to stop these activities but to ensure they can continue without damaging the environment. Hence, it is necessary to define the rules that will govern each activity, the types of development compatible with preserving the area and those that are totally unacceptable. This work requires detailed consultations with all the parties involved.

Finally, once this work was completed, the EDYTEM team were required to draw up documents presenting the area to be protected and its heritage resources (poster + small pamphlet) for the general public. A certain amount of expertise was needed for determining the karst resources and landscapes to be protected. However, it was also necessary to take into account the affects of the protection measures on the numerous interests impacted by the project. 


\section{WORKING METHODS}

The EDYTEM team brought together experts with the different but complementary skills that would be needed to successfully complete the various phases of the project. Work began by carrying out a survey of the extensive literature on the massif and its karst network produced by cavers, archaeologists, palaeontologists, ethnologists specialising in local history and, of course, karst geographers. In addition, cavers from the "département" of Isère (Comité Départemental de Spéléologie), with whom EDYTEM has long had a good working relationship, provided cave inventories and topographical surveys.

This data formed the basis for a comprehensive atlas of the network that includes information on the plateau's heritage resources, current protection measures (Natura 2000 zones, special bird protection areas, etc) and existing economic activities, etc. The mapping work was completed by a photographic survey of the area (including work by professional photographers) showing the under- ground and surface landscapes. These documents were drawn up for use during the steering committee's meetings with the various interested parties, in order to show how work was progressing, as well as for inclusion in the classification dossier.

Compiling the protection dossier and management guidelines required detailed consultations with local interests and numerous information and fact-finding meetings with all the interested parties. Strenuous efforts were made to take into account all forms of land-use and to avoid needlessly upsetting people, so as not to create unnecessary difficulties. The most delicate part of this consultation phase was presenting the boundaries of the proposed protection area, as every interested party found reason to object, based on their own interests and their own perception of the area. Hence, the scientific work had to take into account the local interests that were uncovered as the project progressed.

\section{STAKES}

The most important sector to be affected by the project to list the Choranche Caves and the Coulmes Plateau will undoubtedly be tourism. The operator of the Choranche Caves has always supported the protection project because the prospect of being awarded UNESCO World Heritage status is seen as a marvellous opportunity to give a much-needed boost to the site. The Choranche Caves are the biggest pay-to-enter tourist attraction in the Vercors Mountains and the only one to be open all year round; the area's other tourist sites are all highly seasonal with summer and winter peaks. Visitors are also attracted to the area around the caves by outdoor sports, such as rock climbing on the cliffs at Presles (which have been popular with climbers since the 1970s), cross-country skiing and hiking. As a result, there are several accommodation providers on the plateau and in the village of Choranche. When asked, local people are unanimously in favour of these outdoor activities, as they are seen as a source of jobs, but this does not prevent conflicts between visitors and locals over issues such as parking and access to the climbs. The plateau's local councillors sometimes seem more concerned by any nuisance caused to farmers than by the economic benefits gained by the area's accommodation providers. The public debates have shown greater disagreement than expected over the tourism issue, with not everyone in the area considering it a priority.
It has become apparent that local attitudes to the protection project are shaped by individual opinions on tourism. In addition, the introduction of protection measures as a step towards obtaining UNESCO World Heritage status is seen as a double-edged sword. If the French government's UNESCO project succeeds, almost everyone agrees the benefits will be positive. However, opponents argue that if the UNESCO project fails, listing the site will hinder any form of development on the plateau. This standpoint results from a deep misunderstanding of the need to protect this karst environment and the blind opposition of the plateau's politicians and the valley's inhabitants. The biggest fear, which has been expressed very clearly, is that nearly all the project's benefits will go to Choranche, as tourist flows will be channelled through the gorge to the caves. Consequently, the villages on the plateau will be subject to restrictions that will constrain their development, without receiving any of the benefits. These territorial differences in opinion are exacerbated by differences in peoples' mentalities. The people of Choranche have long appreciated the benefits brought by tourism, starting with a spa that thrived from the $19^{\text {th }}$ century until the 1930 s. On the other hand, the plateau's inhabitants feel as though they have only ever received the crumbs left after Choranche has eaten most of the tourist cake. Presles' elected representatives have particular difficulty in understanding that it is up to them to find ways in which to reap benefits from 


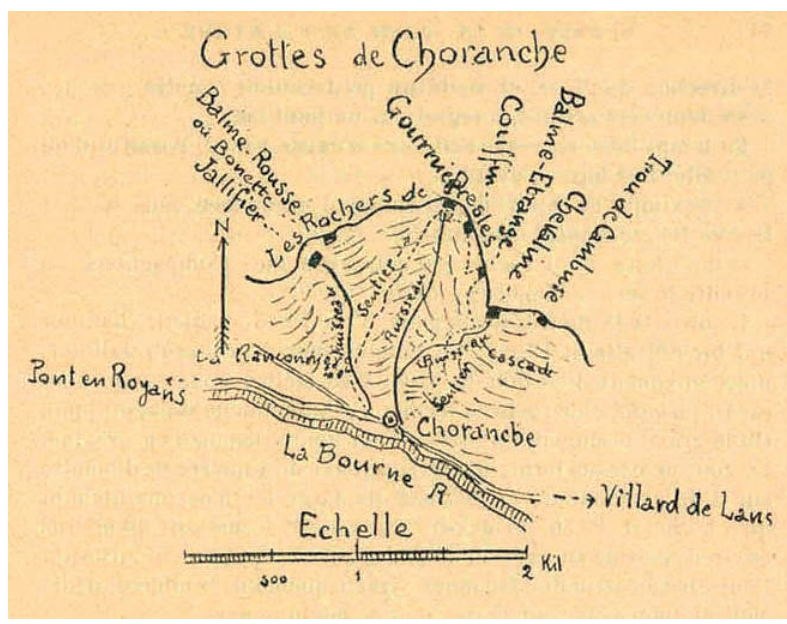

Fig. 2: Choranche cirque and the location of main caves, drawn by Oscar Décombaz, 1898.

being listed a World Heritage site; it is their responsibility to ensure Choranche does not take all the pickings.

There is also a conflict between the plateau and the gorge over the issue of water, another element that is central to this project. Although everyone agrees on the importance of water, there are deep disagreements about how this resource should be used. Therefore, water's place in the system must be defined: as well as being a resource for the local population, it is an essential part of the area's heritage that must be preserved. For example, during the 1990s, Presles council proposed drilling through the plateau to tap into the Gournier underground river in order to resolve its chronic water shortage problems. The project was only abandoned, albeit provisionally, when local cavers proved it technically unfeasible. This was a bitter disappointment for the plateau's politicians, who are reluctant to definitively discard the idea. However, diverting these waters could not be authorised under any protection scheme, as the Gournier feeds the famous tufa falls that form such an important part of the site's landscape. If a water extraction scheme were to be permitted, the largest reductions in water flows would be in summer and it is in summer, when air temperatures are relatively high, that the Gournier's waters deposit the greatest

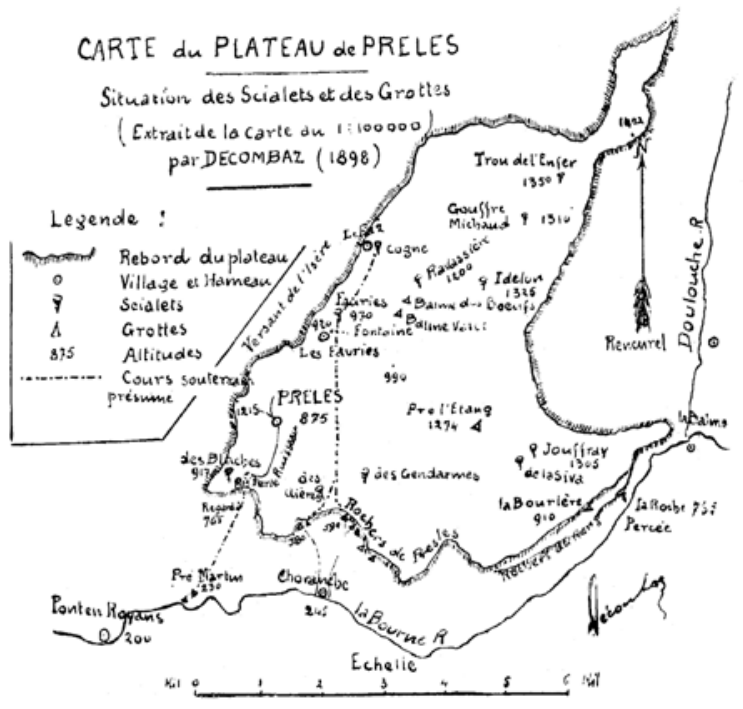

Fig. 3: Sketch of the Coulmes Plateau by Oscar Décombaz, 1899, with location of caves and pot-holes (scialets).

amount of tufa. There is an enormous gulf between those who perceive water as a resource to protect and those who regard it as a resource to exploit. Although positions on this issue are rarely explicitly stated, they have played a central role in the debates over the protection project. Paradoxically, the waterfalls themselves cannot be protected under the terms of the $1930 \mathrm{Act}$, as the Act cannot protect water, only the landscape surrounding it. Hence the importance of the management guidelines, which will include precise recommendations on how the water is to be protected. A traditional "water culture", as is found in Mediterranean karst areas, has not developed in the Vercors Mountains. This may be due to the area having a particularly humid climate $(\mathrm{Ppn}>2000 \mathrm{~mm})$ in which, historically, there has been little need to conserve what is seen as an abundant resource. As a result, when faced with increases in demand, both for agricultural and for domestic use, the only solution local politicians were able to envisage was to find other sources to increase the supply to users.

\section{CHORANCHE'S KARST RESOURCES}

A comprehensive inventory, in the form of themed data sheets, of all the karst resources to be found in the Choranche area was drawn up for inclusion in the protection dossier. Without reproducing the full inventory, we would like to give an idea of the diversity and richness of the heritage resources of the Choranche Caves and the Coulmes Plateau.

\section{CAVE FORMATIONS}

The original motivation behind the UNESCO World Heritage project was a desire to protect and promote the area's cave formations, including the spectacular Coufin soda straws that have made Choranche famous. Given their aesthetic qualities and the role they play in attract- 
ing tourists to the Choranche Caves, agreement on the need to preserve these exceptional formations was immediate and unanimous. Even if visitors to the caves only take away one memory, it is of the thousands of strands of "spaghetti" reflected in the waters of the lake and river at Coufin. For many years, the tourist route through the cave has been screened by windows in order to protect the formations from direct damage. However, a wider preservation area will have to be defined if these formations are to be given more global protection. This has proven to be a very delicate issue. Although the UNESCO presentation dossier only specifically covers the cave formations, these formations cannot be preserved unless the environment in which they formed is protected. But, how extensive should this protected area be? Should it only cover the land immediately above the caverns? Or should it include the area that feeds water to the formations, in so far as it can be defined, bearing in mind that the stratification of the rock will doubtlessly create areas of lateral transfer? Or should it extend to the entire hydrogeological system? Scientists must provide precise answers to these questions - answers on which to base clear and coherent arguments that will convince sceptics. Given the need to protect a large area of the karst in order to protect the cave formations, it is unfortunate that the UNESCO proposal only explicitly mentions the "formation-bearing caves". This has proved to be a major obstacle to the protection process, as it enables opponents to argue that only the soda straws themselves should be listed. However, because of the way in which karst systems work, a much more extensive area must be protected if the formations are to be properly preserved. Hence, the idea of listing the "formation-bearing caves" may actually work against the protection of the karst system: something that the promoters of the project undoubtedly never imagined.

\section{THE KARST SYSTEMS}

The karst systems themselves are utterly remarkable. In fact, there are three perched systems, with no saturated zones, cut by the incision of the Gorges de la Bourne. Other similar systems can be found in the French PreAlps, but the three aligned springs at the foot of the Coulmes escarpment are particularly spectacular. Cavers have followed and mapped the underground rivers over distances of several kilometres, following the River Gournier, for example, for almost six kilometres under the plateau to its terminus 680 metres above the spring. These systems are made up of highly complex networks of tunnels and chambers of all shapes and sizes. For instance, the Gournier Cave boasts a subterranean river that flows beneath a vast fossil gallery, the galleries of the Coufin Cave form a true labyrinth and the River Chevaline flows over a succession of large gours before emerging at a spring that is uniquely gravity-fed. Although most of the parties concerned by the protection project are aware of these underground landscapes, they have little idea of their diversity. One of the objectives of the photographic survey of the area is to raise awareness of this difficult-tovisualise dimension.

\section{PALAEONTOLOGICAL, ARCHAEOLOGICAL AND HISTORICAL REMAINS}

Palaeontological, archaeological and historical remains: Large quantities of fossils, particularly the remains of bears, have been found in some of the caves on the plateau (especially the Pré l'Etang cave) and in the upper fossil levels of the Coufin Cave. The Pré l'Etang deposit has been intensively studied; however, the Bear Gallery in the Coufin Cave, which is at the end of the known network and very difficult to reach, has never been visited by palaeontologists. Despite being discovered by some of the cave's earliest explorers, the species of bears to be found there have never been described. In addition, explorations of some of the cavities in the rocks of the Choranche Cirque have revealed prehistoric remains, but undoubtedly not enough for the Cultural Affairs Department to classify these rock shelters as "historic monuments". As well as these prehistoric remains, there are archaeological relics from the more recent past, such as those left by the plateau's charcoal burners, including settlements that have been abandoned since the beginning of the $20^{\text {th }}$ century. In the caves themselves, and especially in the Balme Etrange, signatures dating back to the 1830 s can be found on the walls: proof of the long history of tourism in the Choranche Cirque and confirmation of some of the information found during the literature survey. Therefore, the historic interest of the site cannot be denied.

\section{EXO-KARSTIC STRUCTURES AND FORMATIONS}

Exo-karstic structures and formations are extremely abundant, providing a link between the scientific and picturesque interests of the site. The Choranche Cirque contains the most spectacular formations, most notably the large tufa flows that dot the Gournier stream. About ten years ago, the visitor trail was extended to include these tufa flows and signposts were erected to explain how they formed and their palaeoenvironmental significance.

On the plateau, such formations are usually less easily visible because of the dense forest cover, but they are just as interesting. The Pot Siva area contains a group of roofless caves that can be explored and that contain the remains of speleothems. Despite being particularly well developed, the cone karst, which provides evidence of the phases of karst formation during the Tertiary, cannot easily be seen due to the lack of a viewpoint overlooking the 
whole area. In fact, this is the only part of the Vercors to contain such a diversity of karst structures, and this alone should provide sufficient justification for listing the area.

\section{THE LANDSCAPE RESOURCE}

The landscape resource: In addition to the elements mentioned above, the landscape as a whole exudes a special atmosphere that adds to the area's beauty. This atmosphere mostly comes from the stark contrasts that characterise the area: the juxtaposition of gorge and plateau, barren cliffs and luxuriant undergrowth, narrow defiles and open plateaux, dark caverns and luminous cirques, and the abrupt transitions between the vertical and the horizontal. The spectacular view of the Cirque de Choranche from the caves car park always makes a vivid impression on visitors; however, it is important to make them realise that they will only get a complete picture of the area's natural wealth if they continue their excur- sion onto the plateau. By doing this, they will also be able to appreciate the variety of the area's vegetation, which changes from the beech-pine forest so typical of the cool and humid Northern Pre-Alps to a sub-Mediterranean boxwood-juniper assemblage. These changes are governed by altitude, as the plateau gradually descends from a height of 1450 metres in the north to 850 metres in the south, before plunging past the Coufin cave entrance (at $590 \mathrm{~m}$ ) to the bottom of the gorge and the village of Choranche at 270 metres. More than half a century ago, the caver André Bourgin suggested that the "Coulmes area of the Vercors showed the characteristics of the whole massif in miniature" (1950, p. 16). This concentration of karst landscapes in an area of only $40 \mathrm{~km}^{2}$ is another of the riches of the Coulmes Plateau and further justification for protecting the site - especially in a country that has not, as yet, given official protection to any of its mid-altitude forest karsts.

\section{DIFFICULTIES}

Current French law and Department of the Environment guidelines contain five criteria for assessing whether protecting a site is in the general interest. The Choranche Caves and Coulmes Plateau satisfy three of these five criteria; therefore, the task of producing a protection dossier should have been very straightforward. In fact, a number of obstacles quickly appeared, including the refusal by some local people to accept the recommendations of the experts who are compiling the dossier. Surmounting these problems will probably be extremely difficult as they are based on fears that listing the area will seriously hamper development without providing significant benefits.

Although the 1930 Act defines the introduction of protection measures as a purely administrative procedure, in practice it requires a participative approach involving the local population: a reality that does not always make life easy. In addition, the public debate on the protection project provided a forum for expressing old frustrations that were not necessarily connected with the protection project. Reactions may have been particularly vehement due to people feeling that local infrastructure needs had, for many years, been neglected. Many local people could not understand why listing the site was suddenly so important, as there was no immediate threat to the area. They felt that their ability to manage their own area was being called into question. Listing the site quickly became a local political issue that could only be understood in local terms and opposition to the project has been increased by the solidarity between local communities. For example, to avoid angering its neighbours, Choranche, which has everything to gain from the project, has rallied to the cause of Presles, which is hostile to anything other than a very limited protected area. Therefore, the project has lost the support it expected to receive from Choranche. Local politicians and competing institutions (Regional Nature Park, Association of local councils, etc) are also trying to make political capital from the protection project. And no one knows if the hostility of the area's regional councillor is related to him being a quarry owner! 


\section{CONCLUSION}

At the current time, the Choranche Caves protection dossier is still being finalised and the full listing process is far from being finished. The dossier will be presented for examination by the "Départementale" Commission and the "Commission Supérieure des Sites", and then it will probably go to ministerial arbitration before the listing can be approved by the Conseil d'Etat, France's highest administrative body. To be successful, the protection project will require strong and sustained political support. The importance of this political dimension came as a surprise to both the laboratory's team of scientists and to the Department of the Environment, which had not expected such strong opposition.

Nevertheless, the process has been extremely useful - it has shown the strength of public opinion and the awareness of the local population and their elected representatives of the need to consider the karst area in which they live as a precious resource that must be carefully managed. Even though these communities have been part of a Regional Nature Park for 35 years, despite the fact that there has been more than a century of exploration and tourism in the caves, although the tourist image of the Vercors is based on a preserved mountain environment and despite 20 years' scientific work to explain karst processes in layman's terms, local politicians and a large section of the population are still unable to accept the need to give the karst active protection. Most local people now understand that the individual parts of the karst are merely components in a coherent and fragile whole. However, as soon as an attempt is made to explain what this means in terms of managing the karst, this "whole karst" concept is quickly forgotten if it is contrary to individual vested interests.

France undoubtedly needs to develop a much more active karst protection policy. Forming a National Council for Underground Heritage, as is being considered by the Minister of Ecology, would raise awareness of this need and listing the Choranche Caves would be seen as a major step forward in the management of karst heritage resources.

\section{REFERENCES}

Bourgin, André, 1950: Rivières de la nuit.- Arthaud, 26 p. +52 plates.

Corbel, Jean, 1956: Le karst du Vercors.- Revue de Géographie de Lyon, $\mathrm{n}^{\circ}$ 3, p. 221-241.

Décombaz, Oscar, 1898: Les grottes de la vallée de la Bourne et du Vercors.- Spelunca, Mémoires de la Société de Spéléologie, t. III, $\mathrm{n}^{\circ} 13,54 \mathrm{p}$.

Décombaz, Oscar, 1899: Explorations souterraines dans le Royans et le Vercors.- Spelunca, Mémoires de la Société de Spéléologie, $\mathrm{n}^{\circ} 22,52 \mathrm{p}$.

Delannoy, Jean-Jacques, 1981: Le Vercors septentrional : le karst de surface et le karst souterrain.- Doctoral thesis, Grenoble, 537 p.

Delannoy, Jean-Jacques, 1997: Recherches géomorphologiques sur les massifs karstiques du Vercors et de la Transversale de Ronda (Andalousie).- Thèse d'Etat, 678 p.
Gauchon, Christophe, 1994: Thermalisme et Tourisme en moyenne montagne. Deux stations des Préalpes : Choranche et La Bauche.- Villes d'eaux, histoire du thermalisme, Actes du 117ème Congrès National des Sociétés Savantes, éd. C.T.H.S., p. 381-393.

Lismonde, Baudouin \& Frachet, Jean-Michel, 1979:, Grottes et scialets du Vercors.- Inventaire spéléologique, tome 2 : Vercors Nord, éd. Comité départemental de spéléologie de l'Isère, $345 \mathrm{p}$.

Nicolas, J.-F., 1786: Mémoire sur les maladies épidémiques qui ont régné dans la province de Dauphiné depuis l’année 1780.- Imprimerie royale, Grenoble, 225 p.

Peigne, Bernard \& Charmont, François, 1962: Essai de statistiques spéléologiques : plateau de Presles, massif des Coulmes. 


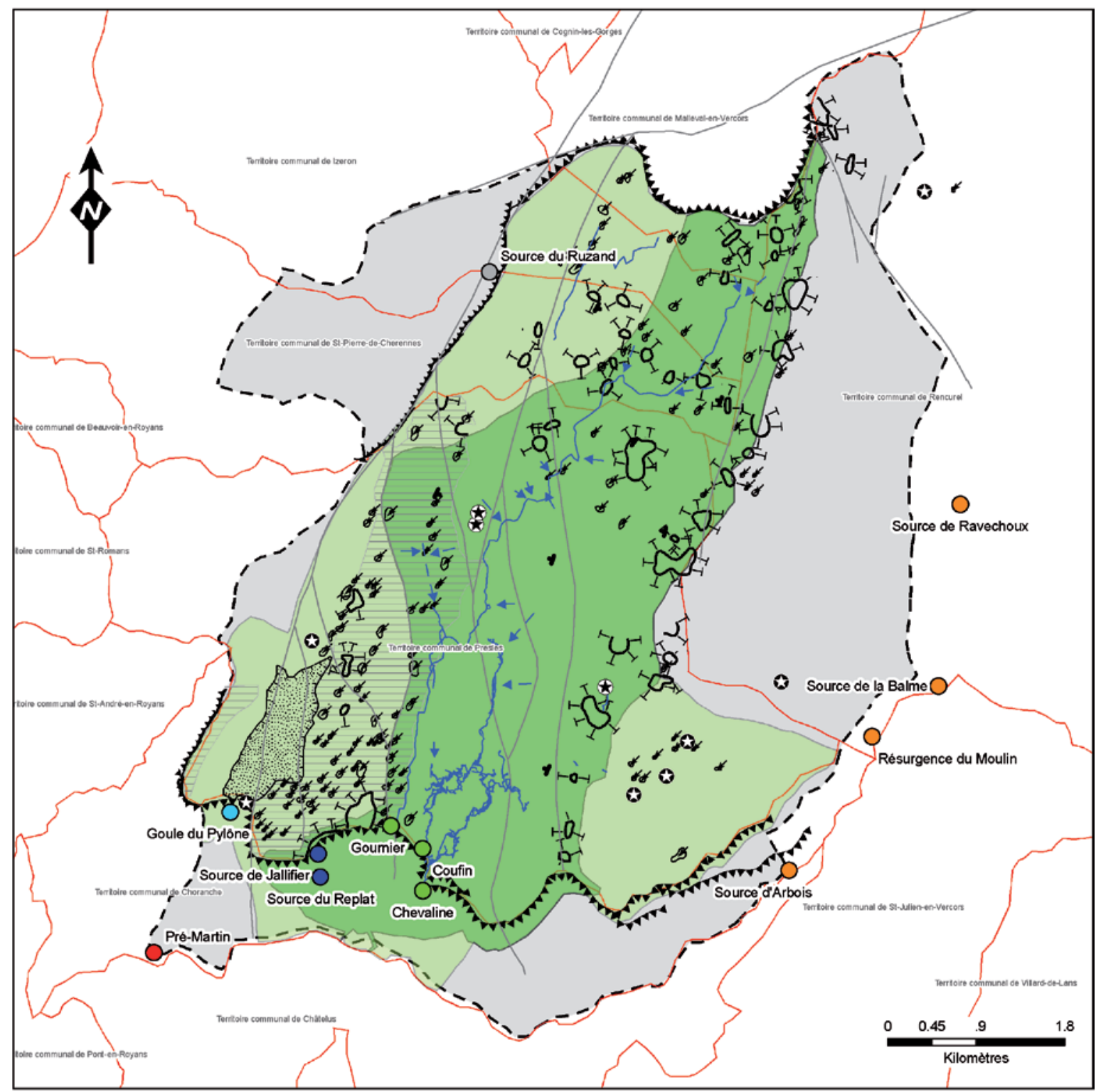

Source des données : J.J. Delannoy, 1997

KARSTIC GEOMORPHOLOGY

KARST HYDROGEOLOGY

* Unroofed caves

* Caves cut by topography

Sorst cones

$\varnothing$ Dolines

(20) Polje

$\exists$ Paleo-polje of Presles

AM Main cliffs

Melinor cliffs Faults
Explored
_ underground networks
KARSTIC SPRINGS
Bury-Pré Martin
Choranche
Fauries-Jallifier
East side of Plateau
Presles-Pylône
Ruzand

PROPOSALS FOR A PROTECTED AREA

Speleological networks and hydrogeologic basin of Choranche Caves

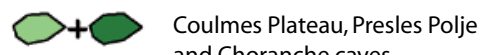

and Choranche caves

I- 1 Study area

Communal boundaries

- Tilt Geomorphology and hydrogeology of Coulmes Plateau

Fig. 4: Geomorphological map of the Coulmes Plateau, with the proposition for the delimitation of protected area. 


\section{LES NOTIONS DE PATRIMOINE ET DE RESSOURCE PATRIMONIALE APPLIQUÉES AU KARST : LE CLASSEMENT DU SITE DE CHORANCHE (VERCORS, FRANCE)}

\section{RÉSUMÉ}

En août 2005, le ministère français de l'Ecologie a lancé la procédure de classement des grottes de Choranche et du massif des Coulmes (Nord Vercors, Préalpes). Dans le cadre de la préparation d'un dossier « Patrimoine mondial » de l'Unesco portant sur 18 cavités concrétionnées, il convient en effet que les biens proposés à l'inscription soient bel et bien protégés par l'Etat porteur du dossier. Or, jusqu’à présent, le réseau karstique des grottes de Choranche ne bénéficie d'aucune protection réglementaire. Il fait l'objet d'une exploitation touristique organisée depuis 1967 et qui s'est avérée plutôt respectueuse de la caverne ; si aucune menace directe ne pèse sur cet ensemble karstique, une commune du plateau a longtemps envisagé de capter la rivière souterraine de Gournier, ce qui aurait de graves conséquences sur la formation des tufs à l'aval de l'émergence.

Le dossier de classement doit répondre à trois objectifs : $1^{\circ}$, établir l'intérêt scientifique, pittoresque, historique, artistique ou légendaire du site, car ce sont là les cinq critères prévus par la loi de 1930 qui régit la protection des sites naturels. Dans le cas des grottes de Choranche, les intérêts artistique et légendaire nétant pas concernés, c'est sur les trois autres registres que porte le travail. $2^{\circ}$, définir le périmètre de classement, ce qui est une tâche fort délicate car une partie du plateau est peuplée d'agriculteurs qui craignent pour leur activité. $3^{\circ}$, proposer un cahier de gestion de l'espace classé, en prenant en compte toutes les activités présentes, autant économiques que de loisirs.

Il a donc fallu identifier les nombreuses ressources patrimoniales qui pouvaient justifier la mesure de protection. Au premier rang viennent les concrétions, et surtout les célèbres fistuleuses de Coufin, qui valent au site de Choranche de figurer dans le dossier Unesco. Tous les acteurs s'accordent sur la valeur de ces concrétions, mais les conflits apparaissent dès que sont évoquées les mesures de protection à prendre : car il ne suffit pas de classer la parcelle sous laquelle se trouvent les fistuleuses, mais bien la totalité de la zone d'alimentation des concrétions.
Deuxième ressource, l'eau : le nord-ouest du Vercors constitue un karst forestier de moyenne montagne, abondamment arrosé, mais les communes du plateau disposent de fort peu de ressources en eau, d'où de grandes convoitises qui pèsent sur cette ressource.

Mais l'étude scientifique a fait émerger aussi d'autres ressources patrimoniales. Sur le plan scientifique, c'est le karst des Coulmes dans son ensemble qui mérite d'être protégé : trois grandes rivières souterraines coulent en effet sous le plateau des Coulmes et forment un ensemble d'émergences pénétrables, perchées 400 mètres au-dessus du fond de la vallée de la Bourne. Les réseaux spéléologiques explorés (> $40 \mathrm{~km}$ ) présentent toute la panoplie des formes endokarstiques, alors qu'en surface, c'est un spectaculaire karst à buttes qui est conservé, avec de nombreuses paléo-cavités trépanées. Les cascades de Gournier présentent aussi un complexe de tuf, avec plusieurs dizaines de tonnes produites chaque année. Cette diversité des formes se traduit sur le plan pittoresque car le paysage formé par le cirque de Choranche, dominé par de hautes falaises de calcaires ocres, est grandiose. Ces paysages sont marqués par toute une série de violents contrastes entre le dedans et le dehors, le vertical et l'horizontal, le minéral et le végétal... Enfin, l'intérêt historique, plus discret, n'en est pas moins réel, avec à la fois des gisements archéologiques sous le porche de Coufin, des gisements paléontologiques importants dans plusieurs cavités (Coufin, Pré l'Etang) et les traces d'anciennes visites touristiques, surtout dans la grotte de Balme étrange (années 1830).

L'intérêt patrimonial du site est donc multiple et aisé à démontrer. Tout se complique lorsqu'il s'agit de convaincre les acteurs du bien fondé des mesures de protection à prendre. En effet, si les professionnels du tourisme soutiennent ce projet de classement, il n'en va pas de même des agriculteurs, des chasseurs et d'une partie des propriétaires qui n'approuvent pas cette mesure. On voit par là que la gestion patrimoniale des ressources du karst reste un problème délicat, surtout si un vrai travail pédagogique n’a pas précédé le lancement de ces procédures. 